\title{
Comparisons Nitrogen Use Efficiency in Chickpea under Different Tillage Systems and Soil Residual Nitrogen
}

\author{
Nihal Kayan ${ }^{1}$ İmren Kutlu ${ }^{2 *}$ Nazife Gözde Ayter Arpacioglu ${ }^{1}$ Mehmet Sait Adak $^{3}$
}

\author{
${ }^{1}$ Department of Field Crops, Faculty of Agriculture, Eskisehir Osmangazi University, 26480, Eskisehir, Turkey; \\ ${ }^{2}$ Department of Biosystem Engineering, Faculty of Agriculture, Eskisehir Osmangazi University, 26480, Eskisehir, Turkey; \\ ${ }^{3}$ Department of Field Crops, Faculty of Agriculture, Ankara University, 06100, Ankara, Turkey \\ *Correspondence author: ikutlu@ogu.edu.tr \\ ${ }^{1}$ https://orcid.org/0000-0001-7505-0959, ${ }^{2}$ https://orcid.org/0000-0002-3505-1479, ${ }^{3}$ https://orcid.org/0000-0002-5121- \\ $4303,{ }^{4}$ https://orcid.org/0000-0002-0154-3328
}

Geliş Tarihi: 20.12.2019

Kabul Tarihi: 18.05.2020

Abstract
The main objective of this study was to investigate the effects of different tillage methods and soil residual nitrogen on chickpea nitrogen use efficiency and yield. This research was conducted with two years (2012/2013-2014/2015) period at research field of Faculty of Agriculture, Eskisehir Osmangazi University, Eskisehir, Turkey. The experiment was designed in randomized complete block design as split split plot with three replicates. Main plots were composed to conventional (CT) and reduced tillage (RT). Wheat-wheat (WW); wheat-fallow (WF); wheat-chickpea (WC) crop rotations were placed in sub plots, and four nitrogen doses $(0$, $50,100,150 \mathrm{~kg} \mathrm{ha}^{-1}$ ) were evaluated as sub-sub plots. Plant protein ratio, plant $\mathrm{N}$ ratio and nitrogen utilization efficiency $\left(\mathrm{NU}_{\mathrm{t}} \mathrm{E}\right)$ were higher RT than $\mathrm{CT}$, however nitrogen use efficiency (NUE) and nitrogen uptake efficiency $\left(\mathrm{NU}_{\mathrm{p}} \mathrm{E}\right)$ were higher $\mathrm{CT}$ than $\mathrm{RT}$. Increasing nitrogen doses were not affected the plant protein ratio and plant $\mathrm{N}$ ratio as expected. NUE and $\mathrm{NUpE}$ decreased by increasing nitrogen doses but $\mathrm{NU}_{\mathrm{t}} \mathrm{E}$ increased. All of the traits except for seed yield were significantly affected by years.

Key words: Nitrogen doses, nitrogen use efficiency, tillage, yield

\section{Nohutta Farklı Toprak İşleme Sistemleri ve Bakiye Azota Bağlı Azot Kullanım Etkinliğinin Karşılaştırılması $\ddot{O} z$}

Farklı toprak işleme yöntemleri ve bakiye azotun nohutun verim ve azot kullanım etkinliğine etkisini araştırmak bu çalışmanın temel amacıdır. Araştırma iki yıl süre ile (2012/2013-2014/2015) Eskişehir Osmangazi Üniversitesi Ziraat Fakültesi deneme alanlarında yürütülmüştür. Denemeler bölünen bölünmüş deneme desenine göre üç tekerrürlü olarak kurulmuştur. Ana parsellerde geleneksel ve azaltılmış toprak işleme metodları bulunmaktadır. Buğday-buğday, buğday-nadas ve buğday-nohut ekim nöbeti sistemleri alt parsellere yerleştirilmiş ve dört azot dozu $\left(0,50,100,150 \mathrm{~kg} \mathrm{ha}^{-1}\right)$ alt-alt parseller olarak değerlendirilmiştir. Bitkide protein oranı, bitkide azot oranı ve $\mathrm{NU}_{t} \mathrm{E}$ azaltılmış işlenen topraklarda daha yüksek iken, $\mathrm{NUE}$ ve $\mathrm{NU}_{\mathrm{p}} \mathrm{E}$ geleneksel işlenen topraklarda daha yüksek olmuştur. Artan azot dozları bitkide protein oranı ve bitkide azot oranını beklendiği şekilde etkilememiştir. Artan azot dozları NUE ve $\mathrm{NU}_{\mathrm{p}} \mathrm{E}$ azaltırken, $\mathrm{NU}_{\mathrm{t}} \mathrm{E}$ artırmıştır. Tane verimi hariç incelenen tüm özelliklerde yıllar arasındaki farklılıklar önemli çıkmıştır.

Anahtar Kelimeler: Azot dozları, azot kullanım etkinliği, toprak işleme, verim

\section{Introduction}

Annual rainfall in Central Anatolia is varies between 250-400 mm and a large amount of falls in winter (35\%) and in spring (34\%) seasons. Hot and dry weather becomes dominant during summer season. It has been determined that the water intake in the region is slow and difficult and the loss by evaporation is rapid and easy. (Oner et al., 2016). For this reason, the fallow - cereal rotation system has been necessary in region. The region has semi-arid climate (Kapluhan, 2013) and cereal-fallow crop rotation is important in region for agricultural production due to amount and distribution of irregular precipitation (Baskan and Unver, 2000). The purpose of fallow is that accumulate moisture in soil and eliminate weeds. Furthermore fallow is produce rich soil in terms of nutrients. However, when legumes sown instead of fallow in crop rotation, legumes will leave less moisture than fallow in soil but they will leave inorganic nitrogen close to fallow (Kun et al., 1990). As known, mono culture (fallow - wheat), the same nutrients are being continuously consumed and as a result the balance plant nutrients is being disturbed. Furthermore, nitrate formation and nitrogen mineralization are 
considerably reduced due to soil compacting in this agricultural system (Aksakal, 2004). When the legumes are taken into crop rotation, these drawbacks may be eliminated.

Mouldboard ploughing is excessive used in conventional tillage and it is causing soil compaction and erosion. Conventional tillage method is widely used in our country and all of the stubble is bury in soil. Therefore, erosion increases especially in dry farming areas and the available moisture in soil is lost due to evaporation (Genctan, 2006). Reduced tillage requires less energy than conventional tillage. In other words, reduced tillage contains less intensive and count tillage than conventional tillage (Ozturk, 2014).

The nutrient efficiency is defined as nutrient use and uptake capacity of plants for produce seed yield and biomass. (Gourley et al., 1993). Nutrient efficiency is complex and it involves two basic mechanisms. These; nutrient uptake efficiency (nutrient uptake mechanism is controlled by root secretions and root morphology) and nutrient use efficiency (produced dry matter quantity responsed to unit nutrient) (El Bassam, 1998). The nitrogen efficiency is defined as the economic yield manufactured per unit of soil nitrogen (Moll et al., 1982). Nitrogen efficiency is include nitrogen use efficiency $(\mathrm{NUE})$, nitrogen uptake efficiency $\left(\mathrm{NU}_{\mathrm{p}} \mathrm{E}\right)$ and nitrogen utilization efficiency $\left(\mathrm{NU}_{\mathrm{t}} \mathrm{E}\right)(\mathrm{Ortiz}-$ Monasterio et al., 1997).

Different tillage methods and soil residual nitrogen on chickpea nitrogen use efficiency and yield were investigated in this study by using two tillage methods, three crop rotations, and four nitrogen doses in Central Anatolia Region.

\section{Material and Methods}

The research was conducted during to two years (2012-2013 and 2014-2015) at the experimental area of Faculty of Agriculture, Eskisehir Osmangazi University, Eskisehir, Turkey (39 $48^{\prime}$ N; 30 31' E, $798 \mathrm{~m}$ above sea level). Climatic conditions for Eskisehir were given Figure 1. Long term annual total precipitation was $329.7 \mathrm{~mm}$ and it was 338.5 and $546.1 \mathrm{~mm}$ in the experimental years, respectively. Annual average temperature was $12.65^{\circ} \mathrm{C}$ in $2012-2013$ and $11.13^{\circ} \mathrm{C}$ in 2014-2015. The soil analysis results of experimental area were presented in Table 1 (Anonymous, 2015).

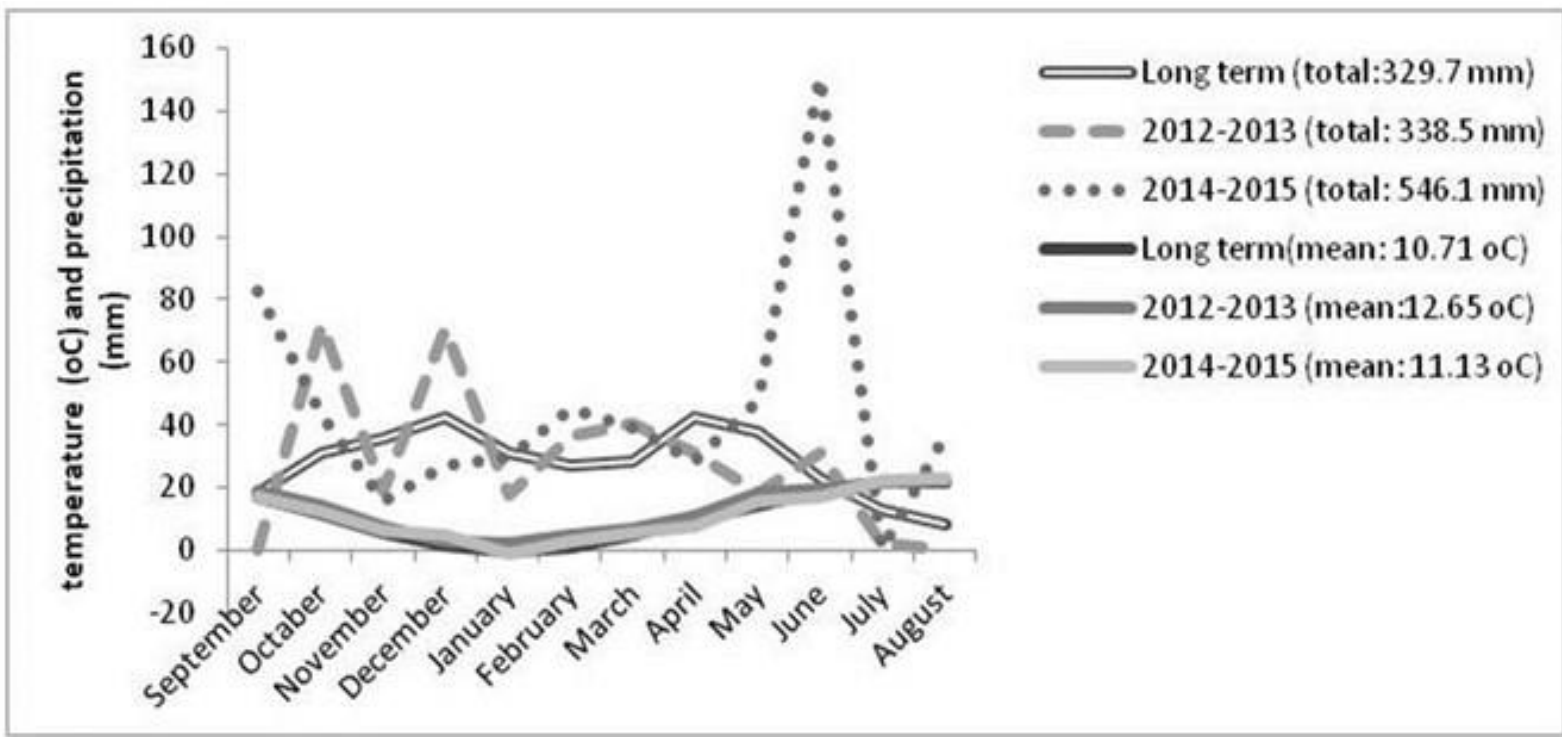

Figure 1. Climatic conditions for experimental area

The field experiment was conducted four years duration (2012-2015). The experiment was designed in randomized complete block design as split split plot with three replicates. Tillage methods (CT: conventional tillage and RT: reduced tillage) were in main plots, crop rotations (WW: wheatwheat; WF: wheat-fallow; and WC: wheat-chickpea) were subplots and $\mathrm{N}$ levels $(0,50,100,150 \mathrm{~kg}$ $\mathrm{ha}^{-1}$ ) were sub-sub plots. First and third years, all of the plots was sown with wheat. Wheat, chickpea and fallow were sown considered on the research plots in second and fourth years. The effect of crop 
rotation was investigated only for wheat plant traits. Only chickpea data were given in this article, since effect of crop rotation could not be evaluated on chickpea. Therefore, the results were evaluated according to split plot with three replicates.

Table 1. Soil characteristic of the experimental site.

\begin{tabular}{lcccccccc}
\hline Year & Texture & $\mathbf{p H}$ & $\begin{array}{l}\text { Total salt } \\
(\boldsymbol{\%})\end{array}$ & $\begin{array}{l}\text { Lime } \\
(\boldsymbol{\%})\end{array}$ & $\begin{array}{l}\text { Organic matter } \\
(\boldsymbol{\%})\end{array}$ & $\begin{array}{l}\mathbf{P}_{\mathbf{2}} \mathbf{O}_{\mathbf{5}} \\
\left(\mathbf{k g ~ h a} \mathbf{1}^{\mathbf{1}}\right)\end{array}$ & $\begin{array}{l}\mathbf{K}_{\mathbf{2}} \mathbf{O} \\
\left(\mathbf{k g ~ h a}^{-\mathbf{1}}\right)\end{array}$ & $\begin{array}{l}\mathbf{N} \\
(\boldsymbol{\%})\end{array}$ \\
\hline $\mathbf{2 0 1 2 - 2 0 1 3}$ & loamy & 7.99 & 0.064 & 3.65 & 1.18 & 34.9 & 2258.6 & 0.05 \\
$\mathbf{2 0 1 4 - 2 0 1 5}$ & loamy & 7.46 & 0.020 & 5.40 & 1.63 & 65.3 & 3630.0 & 0.07 \\
\hline
\end{tabular}

\section{Tillage}

The CT included mouldboard ploughing. Sweep and/or rototiller cultivation followed mouldboard ploughing. The RT included sweep plowing and/or rototiller. CT was tillage $25-30 \mathrm{~cm}$ depth but this depth was 8-10 cm for RT. Tillage practices were performed in September in all years. Empty plots were tilled by rototiller for weeds control when chickpea sown in spring.

\section{Crop rotation}

Three crop rotations were applied. First and third years, all of the plots was sown with wheat. Wheat, chickpea and fallow were sown planned plots in second and fourth years

\section{Fertilization}

Ammonium nitrate as nitrogen fertilizer was applied for wheat. Nitrogen fertilization was divided two parts and applications performed at the sowing time and at beginning of the wheat stem elongation (pre-shooting stage). Nitrogen fertilizer levels were applied to only wheat. Basal fertilizer application of $60 \mathrm{~kg} \mathrm{P}_{2} \mathrm{O}_{5} \mathrm{ha}^{-1}$ (for wheat) and $60 \mathrm{~kg} \mathrm{P}_{2} \mathrm{O}_{5} \mathrm{ha}^{-1}$ and $20 \mathrm{~kg} \mathrm{~N} \mathrm{ha}^{-1}$ (for chickpea) were applied at the sowing time.

\section{Seeding}

Each sub-subplot was $12 \mathrm{~m}^{2}(4 \mathrm{~m} \times 3 \mathrm{~m})$ and cv. Gökçe was used as research material. Chickpea was sown $30 \mathrm{~cm}$ row spacing and seeding rate was 60 seeds $\mathrm{m}^{-2}$. The sowing time was 01 April 2013 and 14 April 2015, respectively. Weeds were removed by hand and herbicide was not applied. Chickpea was harvested on 29 July 2013 and 25 August 2015, respectively.

All of the sub-subplots were harvested separately and the yields of each sub-subplots was found. After crop seeds matured, a $0.5 \mathrm{~m}^{2}$ part was harvested from the each sub-subplot and $\mathrm{N}$ content of straw and seed were determined. Straws and seeds were dried $72 \mathrm{~h}$ at $65^{\circ} \mathrm{C}$ and then they were analysed for total $\mathrm{N}$ by a microKjeldahl method (Bremner and Mulvaney, 1982). NUE is calculated according to the applied nitrogen doses. In addition, the $\mathrm{NU}_{\mathrm{p}} \mathrm{E}$ and $\mathrm{NU}_{\mathrm{t}} \mathrm{E}$ were also determined using various parameters (Moll et al., 1982; Sowers et al., 1994)

$$
\mathrm{NUE}=((\text { yield at } \mathrm{Nx}-\text { yield at } \mathrm{N} 0) \div \text { applied } \mathrm{N})
$$

\section{$\mathrm{NUpE}=(($ total aboveground plant $\mathrm{N}$ at $\mathrm{Nx}-$ total aboveground $\mathrm{N}$ at $\mathrm{N} 0) \div$ applied $\mathrm{N})$}

$$
\mathrm{NUtE}=(\text { (yield at } \mathrm{Nx}-\text { yield at } \mathrm{NO} \div \text { (total avoveground plant } \mathrm{N} \text { at } \mathrm{Nx}
$$

$$
\text { - total aboveground plant } \mathrm{N} \text { at } \mathrm{N} 0) \text { ) }
$$

The variance analysis were subjected according to General Linear Model with the Statview package (SAS Institute). Least Significant Differences (LSD) test was used to compare the means.

\section{Results and Discussion}

Plant protein ratio, plant $\mathrm{N}$ ratio, $\mathrm{NUE}, \mathrm{NU}_{\mathrm{P}} \mathrm{E}$ and $\mathrm{NU}_{\mathrm{t}} \mathrm{E}$ were significantly affected to different tillage methods. Effect of soil residual $\mathrm{N}$ applied wheat on plant protein ratio, plant $\mathrm{N}$ ratio, 
NUE, $\mathrm{NU}_{\mathrm{p}} \mathrm{E}$ and $\mathrm{NU}_{\mathrm{t}} \mathrm{E}$ were significant. Differences between the years were significant in all of the investigated characters except plant protein ratio and seed yield. Year $\times$ tillage interactions were significant for plant protein ratio, plant $\mathrm{N}$ ratio, $\mathrm{NU}_{\mathrm{p}} \mathrm{E}$ and $\mathrm{NU}_{\mathrm{t}} \mathrm{E}$. Plant $\mathrm{N}$ ratio, $\mathrm{NUE}, \mathrm{NU}_{\mathrm{p}} \mathrm{E}, \mathrm{NU}_{\mathrm{t}} \mathrm{E}$ and seed yield were significantly affected year $\times \mathrm{N}$ doses interactions. The effects of tillage $\times \mathrm{N}$ doses interactions on $\mathrm{NU}_{\mathrm{p}} \mathrm{E}$ and $\mathrm{NU}_{\mathrm{t}} \mathrm{E}$ were significant. Differences between the year $\times$ tillage $\times \mathrm{N}$ doses interactions were significant for all of the investigated characters except for plant $\mathrm{N}$ ratio (Table 2). While seed protein ratio, plant protein ratio and seed $\mathrm{N}$ ratio had higher values all of the plots in 20142015 growing season, these traits showed the lower values in 2012-2013 growing season (Figure 2A, B; 3A).

Table 2. Variance analysis and means of the some characters of chickpea for different tillage methods and soil residual nitrogen

\begin{tabular}{|c|c|c|c|c|c|c|c|c|}
\hline Treatments & $\begin{array}{l}\text { Seed protein } \\
\text { ratio } \\
(\%)\end{array}$ & $\begin{array}{l}\text { Plant } \\
\text { protein } \\
\text { ratio } \\
(\%)\end{array}$ & $\begin{array}{l}\text { Seed } \\
\mathbf{N} \\
\text { ratio } \\
(\%)\end{array}$ & $\begin{array}{l}\text { Plant } \\
\mathrm{N} \\
\text { ratio } \\
(\%)\end{array}$ & $\begin{array}{l}\text { NUE } \\
\left(\mathrm{kg} \mathrm{ha}^{-1}\right)\end{array}$ & $\begin{array}{l}\mathrm{NU}_{\mathrm{p}} \mathrm{E} \\
\left(\mathrm{kg} \mathrm{ha}^{-1}\right)\end{array}$ & $\begin{array}{l}\mathrm{NU}_{\mathrm{t}} \mathrm{E} \\
\left(\mathrm{kg} \mathrm{ha}^{-1}\right)\end{array}$ & $\begin{array}{l}\text { Seed yield } \\
\left(\mathrm{kg} \mathrm{ha}^{-1}\right)\end{array}$ \\
\hline CT & 20.03 & $4.22 \mathrm{~B}$ & 3,51 & $0,78 \mathrm{~B}$ & $55.41 \mathrm{~A}$ & $17.48 \mathrm{~A}$ & $25.58 \mathrm{~B}$ & 1331.9 \\
\hline RT & 20.04 & $4.56 \mathrm{~A}$ & 3,51 & $0,85 \mathrm{~A}$ & $41.44 \mathrm{~B}$ & $15.53 \mathrm{~B}$ & $42.24 \mathrm{~A}$ & 1233.4 \\
\hline Mean & 20.03 & 4.39 & 3,51 & 0,81 & 48.42 & 16.50 & 33.91 & 1282.7 \\
\hline 0 kg ha $^{-1} \mathrm{~N}$ & 20.29 & $5.00 \mathrm{~A}$ & 3,56 & $1,06 \mathrm{~A}$ & & & & 1211.2 \\
\hline $50 \mathrm{~kg} \mathrm{ha}^{-1} \mathrm{~N}$ & 20.06 & $3.98 \mathrm{D}$ & 3,51 & $0,69 \mathrm{~B}$ & $72.00 \mathrm{~A}$ & $30.65 \mathrm{~A}$ & $18.62 \mathrm{C}$ & 1260.8 \\
\hline $100 \mathrm{~kg} \mathrm{ha}^{-1} \mathrm{~N}$ & 19.72 & $4.40 \mathrm{~B}$ & 3,46 & $0,77 \mathrm{~B}$ & $43.95 \mathrm{~B}$ & $11.30 \mathrm{~B}$ & $24.66 \mathrm{~B}$ & 1351.9 \\
\hline $150 \mathrm{~kg} \mathrm{ha}^{-1} \mathrm{~N}$ & 20.08 & $4.18 \mathrm{C}$ & 3,52 & $0,73 \mathrm{~B}$ & $29.32 \mathrm{C}$ & $7.57 \mathrm{C}$ & $58.46 \mathrm{~A}$ & 1306.6 \\
\hline Mean & 20.03 & 4.39 & 3,51 & 0.81 & 48.42 & 16.50 & 33.91 & 1282.7 \\
\hline 2012-2013 & $18.56 \mathrm{~B}$ & $3.96 \mathrm{~b}$ & $3,25 \mathrm{~B}$ & 0,79 & $21.62 \mathrm{~B}$ & $11.93 \mathrm{~B}$ & $22.23 \mathrm{~B}$ & 1178.5 \\
\hline 2014-2015 & $21.51 \mathrm{~A}$ & $4.82 \mathrm{a}$ & $3,77 \mathrm{~A}$ & 0,84 & $75.22 \mathrm{~A}$ & $21.08 \mathrm{~A}$ & $45.59 \mathrm{~A}$ & 1386.9 \\
\hline Mean & 20.03 & 4.39 & 3,51 & 0,81 & 48.42 & 16.50 & 33.91 & 1282.7 \\
\hline Year & $* *$ & $*$ & $* *$ & ns & $* *$ & $* *$ & $* *$ & ns \\
\hline Tillage & ns & $* *$ & ns & $* *$ & $* *$ & $* *$ & $* *$ & ns \\
\hline $\mathbf{N}$ doses & ns & $* *$ & ns & $* *$ & $* *$ & $* *$ & $* *$ & ns \\
\hline Year $x$ tillage & ns & $* *$ & ns & $* *$ & ns & $* *$ & $* *$ & ns \\
\hline Year $x$ N doses & ns & ns & ns & $* *$ & $* *$ & $* *$ & $* *$ & $* *$ \\
\hline Tillage $x$ N doses & ns & ns & ns & ns & ns & $* *$ & $* *$ & ns \\
\hline Year $x$ tillage $x \mathbf{N}$ doses & $* *$ & $*$ & $* *$ & ns & $* *$ & $* *$ & $* *$ & $* *$ \\
\hline
\end{tabular}

ns: non significant, $*: p \leq 0.05, * *: p \leq 0.01$.
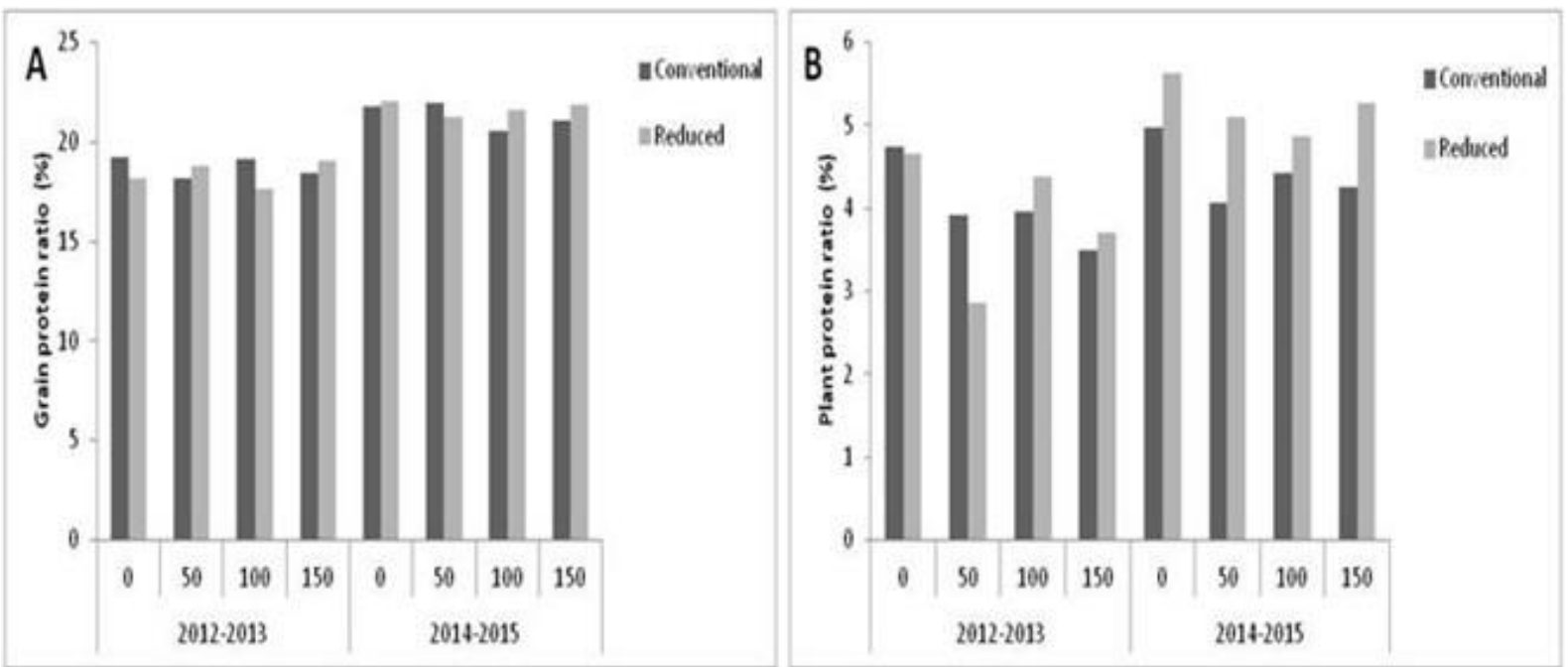

Figure 2. The interaction between tillage methods, years and soil residual nitrogen on seed protein ratio (A) and plant protein ratio (B) of chickpea [LSD1\%: 1.325 (A); LSD5\%: 0.686 (B)]. 
The NUE and $\mathrm{NU}_{\mathrm{p}} \mathrm{E}$ showed highest value on $50 \mathrm{~kg} \mathrm{~N}^{-1}$ and 2014-2015 growing season however $50 \mathrm{~kg} \mathrm{~N}^{-1}$ showed lower value in 2012-2013 growing season (Figure 4B, 5A). The $100 \mathrm{~kg}$ $\mathrm{ha}^{-1} \mathrm{~N}$ levels showed superior performance for $\mathrm{NU}_{\mathrm{t}} \mathrm{E}$ in 2014-2015 growing season however the same $\mathrm{N}$ dose showed lowest values in 2012-2013 growing season (Figure 5B). While $100 \mathrm{~kg} \mathrm{ha}^{-1} \mathrm{~N}$ levels showed superior performance under CT for seed yield in 2014-2015 growing season, the same $\mathrm{N}$ dose showed lower value in the other plots (Figure 6). Plant $\mathrm{N}$ ratio had higher values reduced tillage in 2014-2015 growing season however these traits showed lower values in conventional tillage same year (Figure 3B). While $0 \mathrm{~kg} \mathrm{ha}^{-1} \mathrm{~N}$ levels showed superior performance under 2012-2013 growing season, another $\mathrm{N}$ doses showed lower value in the same year (Figure 4A). For this reason interactions were significant.

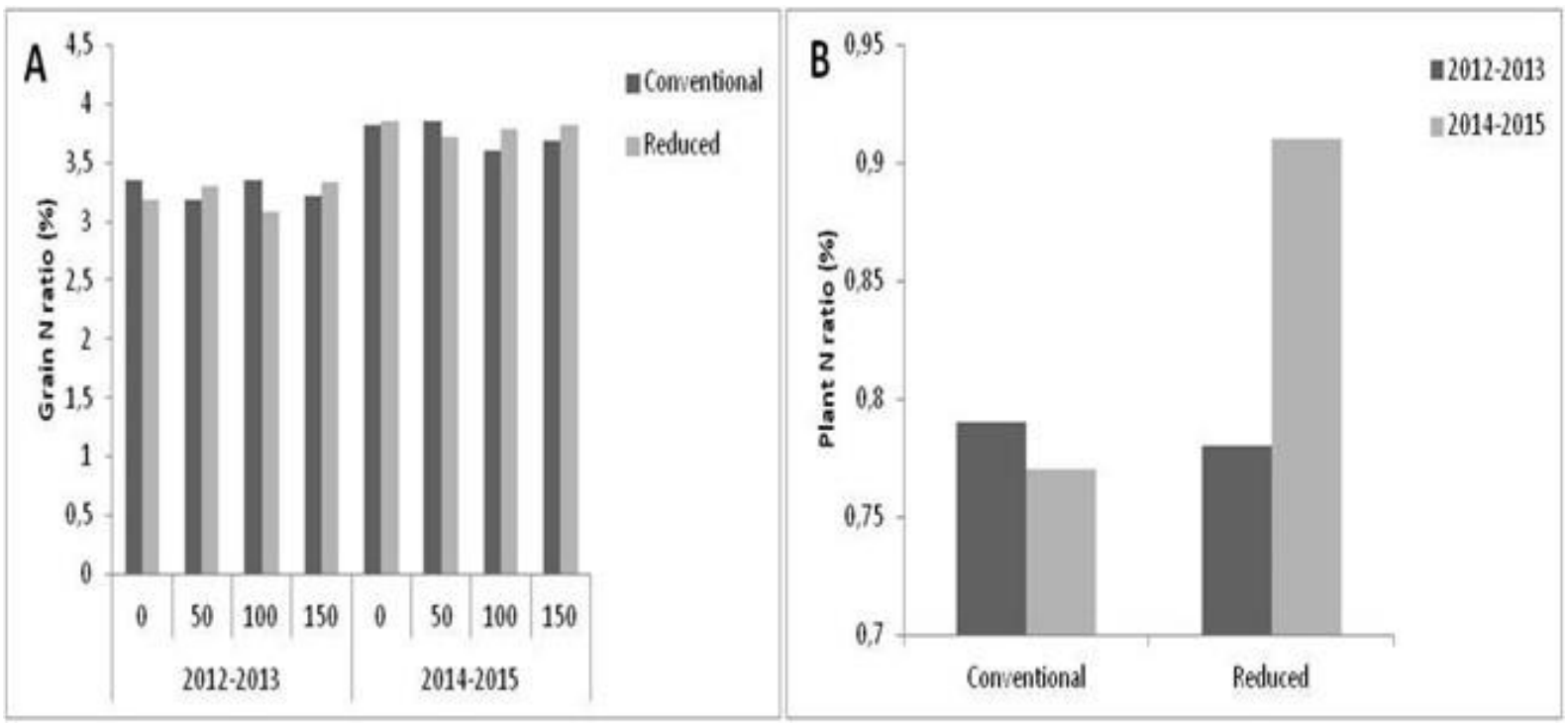

Figure 3. The interaction between tillage methods, years and soil residual nitrogen on seed $\mathrm{N}$ ratio (A) and tillage methods and years on plant $\mathrm{N}$ ratio (B) of chickpea [LSD1\%: 0.228 (A); LSD1\%: 0.059 (B)].

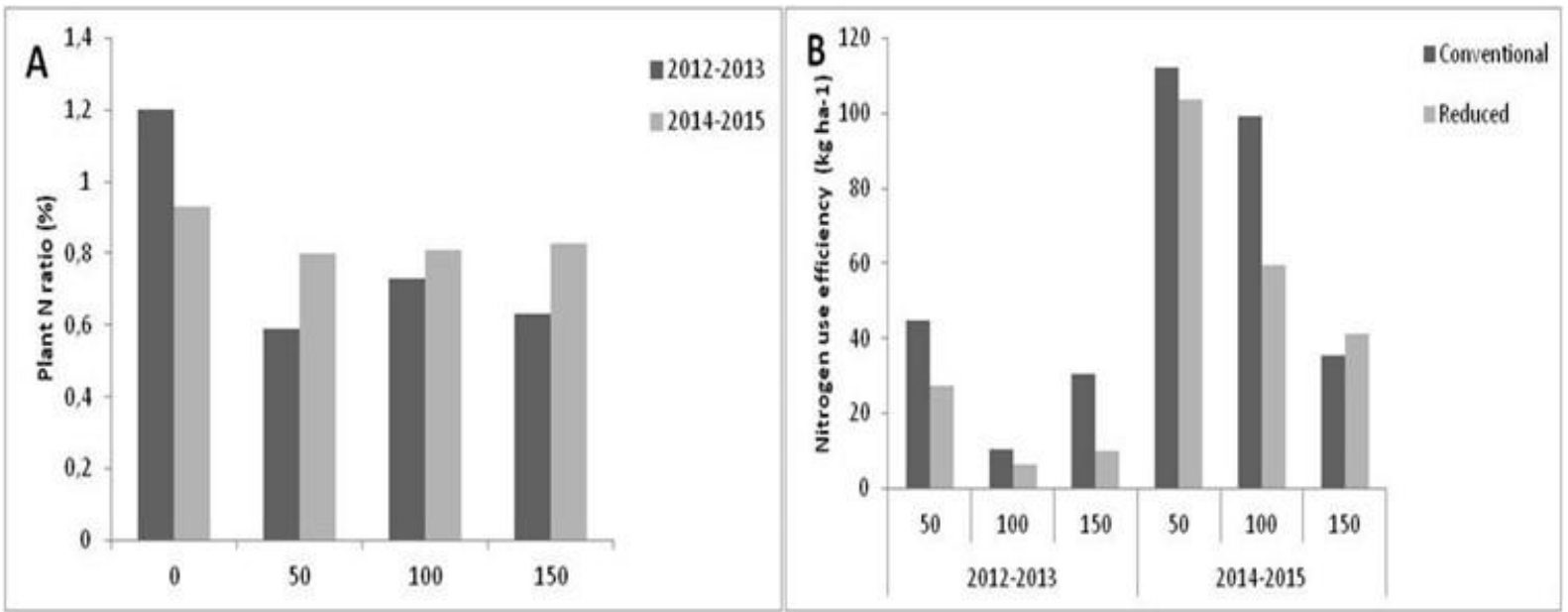

Figure 4. The interaction between years and soil residual nitrogen on plant $\mathrm{N}$ ratio (A) and tillage methods, years and soil residual nitrogen on NUE (B) of chickpea[ LSD1\%: 0.125 (A); LSD1\%: 1.211 (B)].

The seed protein ratio, plant protein ratio, seed $\mathrm{N}$ ratio, plant $\mathrm{N}$ ratio, $\mathrm{NUE}, \mathrm{NU}_{\mathrm{p}} \mathrm{E}$ and $\mathrm{NU}_{\mathrm{t}} \mathrm{E}$ were higher in 2014-2015 growing season than 2012-2013 growing season (Table 2). Uzun et al. (2012) indicated that seed protein ratio of chickpea can be varied between $16.4 \%$ and $31.12 \%$ and seed protein ratio is affected both of the genotypic and environmental conditions. Gul et al. (2007) indicated that seed protein ratio was highly influenced by climatic conditions in growing season. 
Nitrogen intake is higher in high temperature and rainfall (Muchow, 1994). Differences between years for seed protein ratio and plant protein ratio might be occurred ecological conditions, cultural practices and soil factors. NUE and $\mathrm{NU}_{\mathrm{t}} \mathrm{E}$ might be high due to high seed yield in 2014-2015 growing season (NUE: Seed yield / applied N; $N_{t} E$ : Seed yield/total aboveground plant N). NUE and $N_{\mathrm{p}} E$ were higher in 2014-2015 growing season than 2012-2013 growing season. While the 2012-2013 total precipitation was $338.5 \mathrm{~mm}$, the total precipitation was $546.1 \mathrm{~mm}$ in 2014-2015 growing season (Figure 1). Muchow (1994) found that $\mathrm{N}$ uptake and use of plants were limited by temperature and humidity and these traits were higher when temperatures and humidity were high.

Plant protein ratio, plant $\mathrm{N}$ ratio and $\mathrm{NU}_{\mathrm{t}} \mathrm{E}$ were higher $\mathrm{RT}$ than $\mathrm{CT}$ but $\mathrm{NUE}$ and $\mathrm{NU}_{\mathrm{p}} \mathrm{E}$ were higher CT than RT. The higher NUE in CT might be due to the higher seed yield compared to the RT. NUE and NUpE were higher in CT than RT (Lopez-Bellido and Lopez-Bellido, 2001; Brennan et.al., 2014). Lopez-Bellido et. al. (2004) indicated that $\mathrm{NU}_{t} \mathrm{E}$ was higher in zero tillage than $\mathrm{CT}$ but Brennan et. al. (2014) reported that the $\mathrm{NU}_{\mathrm{t}} \mathrm{E}$ was higher in CT than RT.

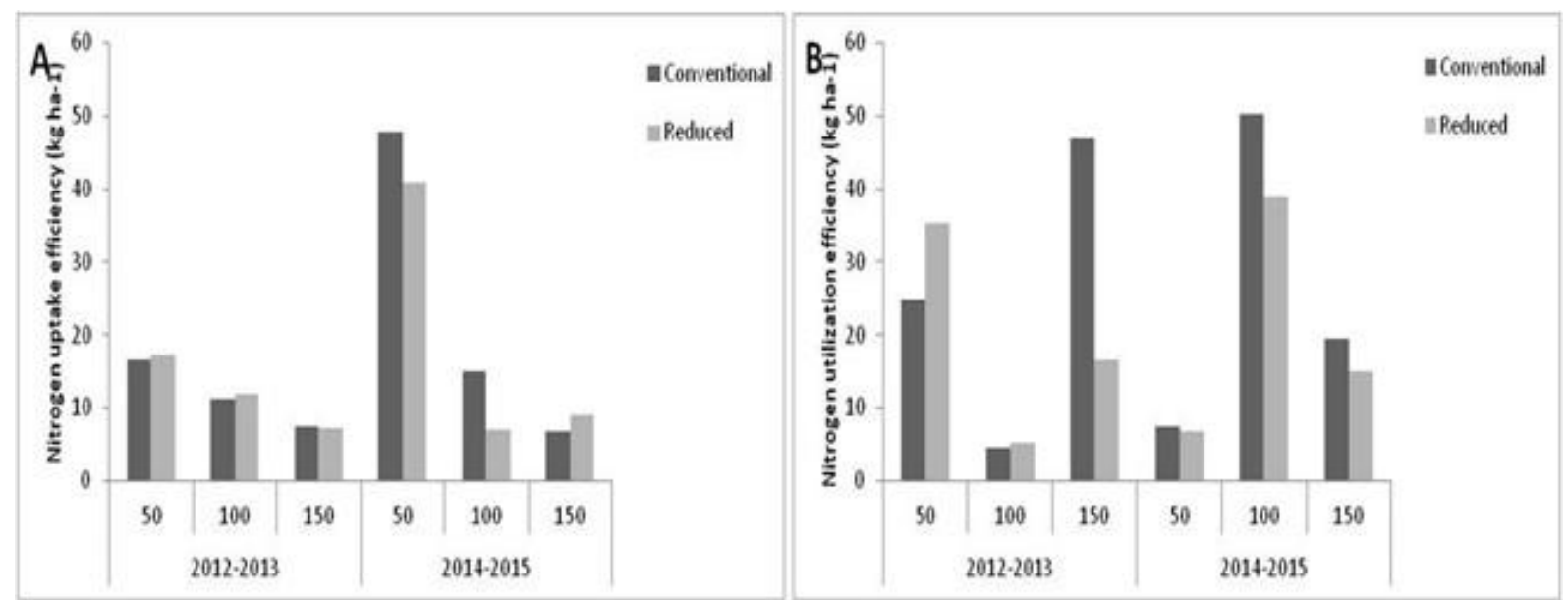

Figure 5. The interaction between tillage methods, years and soil residual nitrogen on $\mathrm{NU}_{\mathrm{p}} \mathrm{E}(\mathrm{A})$ and $\mathrm{NU}_{\mathrm{t}} \mathrm{E}(\mathrm{B})$ of chickpea [LSD1\%: 0.086 (A); LSD1\%: 0.554(B)].

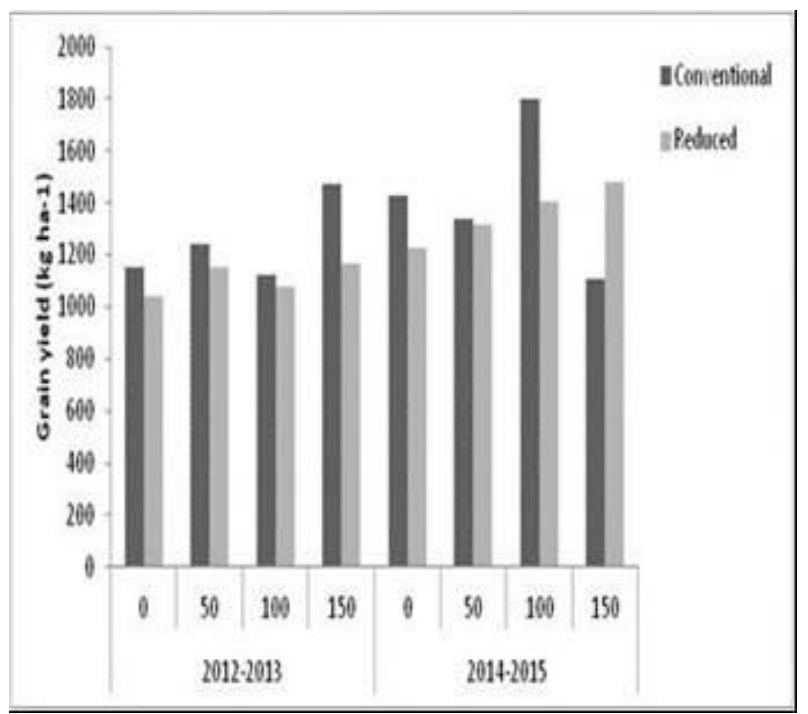

Figure 6. The interaction between tillage methods, years and soil residual nitrogen on seed yield of chickpea [LSD1\%: 391.73].

Increasing $\mathrm{N}$ doses affected the plant protein ratio and plant $\mathrm{N}$ ratio. While the highest plant protein ratio and plant $\mathrm{N}$ ratio were obtained from the $0 \mathrm{~kg} \mathrm{~N}^{-1}$ plot, the lowest plant protein ratio and plant $\mathrm{N}$ ratio were determined in the $50 \mathrm{~kg} \mathrm{~N}^{-1}$ plot. The seed protein ratio and plant protein 
ratio increased depending on the increasing nitrogen doses (Abad et al., 2000; Ottman et al., 2000; Lopez-Bellido et al., 2004; Sumer et al., 2010). Our results were different than expected. Total precipitation in both 2012-2013 and 2014-2015 is higher than the long term. The $\mathrm{N}$ doses were applied to the pre-plant instead of chickpea. The $\mathrm{N}$ might be washed away in this long period from the harvest of wheat to the cultivation of chickpea. Therefore increasing $\mathrm{N}$ doses may not have been affected seed protein ratio, seed $\mathrm{N}$ ratio, plant protein ratio and plant $\mathrm{N}$ ratio in our research. NUE decreased at higher $\mathrm{N}$ doses however it increased at lower nitrogen doses (Table 2). NUE is that seed yield is proportional to applied $\mathrm{N}$ doses (Moll et al., 1982). Therefore, the NUE is lower at higher $\mathrm{N}$ doses (Muchow, 1998). In addition, when the $\mathrm{N}$ is applied excess, the $\mathrm{N}$ taken from the $\mathrm{N}$ fertilizer decrease. When the $\mathrm{N}$ is applied more than necessary, $\mathrm{N}$ losses increase due to washing and $\mathrm{NU}_{\mathrm{t}} \mathrm{E}$ decreases (William and Randall, 1997). Kara (2006) and Maral (2009) reported that there was a negative relationship between $\mathrm{N}$ dose and $\mathrm{N}$ efficiency, also NUE was decreased depending on increasing $\mathrm{N}$ doses. Increasing $\mathrm{N}$ doses were decreased the $\mathrm{NU}_{\mathrm{p}} \mathrm{E}$ (Table 2). $\mathrm{NU}_{\mathrm{p}} \mathrm{E}$ is that beneficial $\mathrm{N}$ in soil is proportional to amount taken by plant (Karasahin, 2014). Kamara et al. (2003) and Kara (2006) reported that the $\mathrm{NU}_{\mathrm{p}} \mathrm{E}$ was decreased depending on increasing $\mathrm{N}$ doses. $\mathrm{NU}_{\mathrm{t}} \mathrm{E}$ was increased due to increasing $\mathrm{N}$ doses (Table 2). Kara (2006) and Maral (2009) reported that $\mathrm{NU}_{\mathrm{t}} \mathrm{E}$ was decreased in low $\mathrm{N}$ doses.

\section{Conclusion}

The plant protein ratio, plant $\mathrm{N}$ ratio and $\mathrm{NU}_{\mathrm{t}} \mathrm{E}$ were higher in the $\mathrm{RT}$ than in $\mathrm{CT}$, while the NUE and $\mathrm{NU}_{\mathrm{p}} \mathrm{E}$ were higher in $\mathrm{CT}$ than $\mathrm{RT}$. Increasing $\mathrm{N}$ doses were not affected the plant protein ratio and plant $\mathrm{N}$ ratio. Because, the $\mathrm{N}$ doses were not applied to chickpea and the $\mathrm{N}$ might be leaching in the long period from the harvest of wheat to the cultivation of chickpea. $\mathrm{NUE}$ and $\mathrm{NU}_{\mathrm{p}} \mathrm{E}$ were decreased at higher $\mathrm{N}$ doses however $\mathrm{NU}_{\mathrm{t}} \mathrm{E}$ was increased due to increasing $\mathrm{N}$ doses. Ecological conditions, cultural practices and soil factors affected differences of years in all traits except seed yield.

\section{Acknowledgements} 201123039

This research was supported in part by Eskisehir Osmangazi University Research Foundation as Project no:

\section{References}

Abad, A., Lloveras, J., Michelena, A., Ferran, J., Royo, C., Nachit, M.M., Fonzo, N., Araus, J.L. 2000. Nitrogen fertilization effects on yield and quality of durum wheat in the Ebro Valley (Spain). Durum wheat improvement in the Mediterranean region: new challenges, Proceedings of a seminar, 12-14 April, Zaragoza, Spain.

Aksakal, E.L., 2004. Soil compaction its importance in terms of agriculture. Journal of Ataturk University Agricultural Faculty. 35(3-4): 247-252.

Anonymous, 2015. Soil and Leaf Analyses Lab of Eskisehir Agriculture Office.

Baskan, O., Unver, I., 2000. Effect of soil profile depth on fallow activity in Ankara conditions. Turkish Journal of Agricultural and Forestry, 24: 721-727.

Brennan, J.R., Hackett, T., McCabe, J., Grant, R.A., Fortune, P.D., Forristal, B., 2014. The effect of tillage system and residue management on grain yield and nitrogen use efficiency in winter wheat in a cool Atlantic climate. European Journal of Agronomy, 54: 61- 69.

Bremner, J.M., Mulvaney, C.S., 1982. Nitrogen-total. (Methods of Soil Analysis. Part 2. Chemical and Microbiological Properties. American Society of Agronomy, (ed.) Miller, R.H., Keeney, D.R., 595-624.

El Bassam, N., 1998. A concept of selection for 'low input' wheat varieties. Euphytica. 100: 95-100.

Genctan, T., 2006. Field Farming. Publications of Namık Kemal University No: 21, Textbook No: 11, Tekirdag, $386 \mathrm{p}$.

Gourley, C.J.P., Ailen, D.L., Russelle, M.P., 1993. Defining phosphorus efficiency in plants. Plant Soil. 155/156: 289-292.

Gul, M.K., Cem, O.E., Kahrıman, F., Turhan, H., 2007. Changes in protein value in some chickpea lines in spring and winter periods under Canakkle conditions.7th Field Crops Congress, July 25-27, Erzurum.

Kamara, A.Y., Menkir, A., Sanginga, N., 2003. Nitrogen use efficiency of maize genotypes improved for tolerance to low nitrogen and drought stress. International Institute of Tropical Agriculture, Ibadan, Nigaria. 
Kapluhan, E., 2013. Drought in Turkey and the effect of drought on agriculture. Marmara Geography Journal. 27: 487-510.

Kara, B., 2006. Determination of the yield and yield component, nitrogen uptake and use efficiency of corn on the different plant density and nitrogen doses in the Cukurova conditions. Çukurova University, Science Institute, Department of Field Crops, PhD Thesis, 162 p.

Karasahin, M., 2014. Nitrogen use efficiency in crop production and negative effect of reactive nitrogen on environment. Academic Platform Journal of Engineering and Science. 2(3): 15-21.

Kun, E., Altay, F., Kalayci, M., Adak, M.S., Tusuz, A., Acikgoz, N., Tugay, M.E., Sencar, O., Meyveci, K., Tan, A., Kurt, O., Karagoz, A., 1990. Decreasing of fallow lands in Turkey and second crop studies. 3rd Technical Congress on Agricultural Engineering, January 8-12, Ankara.

Lopez-Bellido, R.J., Lopez-Bellido, L., 2001. Efficiency of nitrogen in wheat under Mediterranean conditions: Effect of tillage, crop rotation and $\mathrm{N}$ fertilization. Field Crops Research. 71: 31-46.

Lopez-Bellido, R.J., Lopez-Bellido, L., Castillo, J.E., Lopez-Bellido, F.J., 2004. Chickpea response to tillage and soil residual nitrogen in a continuous rotation with wheat II. soil nitrate, $\mathrm{n}$ uptake and influence on wheat yield. Field Crops Research. 88: 201-210.

Maral, H., 2009. Response of oat cultivars to nitrogen fertilization for grain yield, nitrogen use an yield traits. University of Kahramanmaras Sutcu Imam, Science Institute, Department of Field Crops, Msc Thesis, $61 \mathrm{p}$.

Moll, R.H., Kamprath, E.J., Jackson, W.A., 1982. Analysis and interpretation of factors which contribute to efficiency of nitrogen utilization. Agronomy Journal. 74: 562-564.

Muchow, R.C., 1994. Effect of nitrogen on yield determination in irrigated maize in tropical and subtropical environments. Field Crops Research. 38(1): 1-13.

Muchow, R.C., 1998. Effect of nitrogen supply on comparative productivity of maize and sorghum in a semiarid tropical environment, III. grain yield and nitrogen accumulation. Field Crops Research. 18: 31-43.

Ortiz-Monasterio, J.I., Sayre, K.D., Rajaram, S., McMahon, M., 1997. Genetic progress in wheat yield and nitrogen use efficiency under four nitrogen rates. Crop Science. 37: 898-904.

Ottman, M.J., Doerge, T.A., Martin, E.C., 2000. Durum grain quality as affected by nitrogen fertilization near anthesis and irrigation during grain fills. Agronomy Journal. 92(5): 1035-1041.

Oner, N., Ersahin, S., Ayan, S., Ozel, H.B., 2016. Rehabilitation of semi-arid lands in Central Anatolian. Anatolian Journal of Forest Researches. 2(1-2):32-44

Ozturk, F., 2014. Specification of the effect of the different tillage equipment on the residue cover on the soil via samplepoint and line transect methods. University of Kahramanmaras Sutcu Imam, Science Institute, Department of Biosystem Engineering, Msc Thesis, 63 p.

Sowers, K.E., Pan, W.L., Miller, B.C., Simith, J.L., 1994. Nitrogen use efficiency split nitrogen applications in soft white winter wheat. Agronomy Journal. 86(6): 942-948.

Sumer, F.O., Erekul, O., Koca, Y.O., 2010. The effect of different nitrogen doses and plant density on bread wheat (Triticum aestivum L.) cultivars yield, yield component and bread-making quality. Anatolian Journal of Agricultural Sciences. 20(2): 28-44

Uzun, A., Ozcelik, H., Yilmaz, S., 2012. Evaluation of some selected chickpea (Cicer arietinum L.) lines in respect to agronomic and quality traits. Academic Agriculture Journal. 1(1): 29-36.

William, J.E., Randall, G.W., 1997. Rate of fertilizer nitrogen an affected by time and rate of application on corn. Soil Science Society of America Journal. 61: 1695-1703. 